Article

\title{
Parameter Localization of Greenhouse Gas Value Model and Greenhouse Gas Storage Simulation for Forest Ecosystems in China
}

\author{
Mengdi Li ${ }^{1,2}$, Yaoping Cui ${ }^{1,2,3, * \mathbb{C}}$, Yaochen Qin ${ }^{1,2}{ }^{\mathbb{D}}$, Oliva Gabriel Chubwa ${ }^{1,2}$, Yiming Fu ${ }^{1}$, \\ Nan $\mathrm{Li}^{1}$, Xiaoyan Liu ${ }^{2}$ and Yadi Run ${ }^{2}$ \\ 1 Key Laboratory of Geospatial Technology for the Middle and Lower Yellow River Regions, \\ Kaifeng 475004, China; lmd@cug.edu.cn (M.L.); qinyc@henu.edu.cn (Y.Q.); \\ oliva2020@vip.henu.edu.cn (O.G.C.); fym0521@vip.henu.edu.cn (Y.F.); linan0716@henu.edu.cn (N.L.) \\ 2 College of Environment and Planning, Henan University, Kaifeng 475004, China; \\ lxy@henu.edu.cn (X.L.); run@henu.edu.cn (Y.R.) \\ 3 Key Laboratory of Integrative Prevention of Air Pollution and Ecological Security of Henan Province, \\ Kaifeng 475004, China \\ * Correspondence: cuiyp@lreis.ac.cn; Tel.: +86-139-3785-8607
}

Received: 25 August 2020; Accepted: 28 October 2020; Published: 30 October 2020

\begin{abstract}
Quantifying the greenhouse gas (GHG) storage in forest ecosystems can support global change directly, from a biogeochemical perspective. However, accurately assessing the amount of GHG storage in forest ecosystems still faces challenges in China because of their wide distribution, varying types, and the changing definitions and areas of forests. We used land-use data with 5-year intervals during 1990-2015 to investigate the spatiotemporal variations of forest ecosystems in China. As three major greenhouse gases in forest ecosystems, the potential storage of carbon dioxide, methane, and nitrous oxide can be calculated by a greenhouse gas value (GHGV) model. The results showed that the total area of forest ecosystems decreased by $15 \times 10^{5}$ ha during the study period. The area of forest ecosystems reached its highest level in 1995 and then declined. For various forest ecosystem types, shrubbery (Sh) increased by $0.82 \%$ but the broad-leaved forest, evergreen coniferous forest (ECF), and mixed forest (MF) all showed a downward trend. Correspondingly, the potential GHG storage of forest ecosystems declined from $156.97 \mathrm{Pg} \mathrm{CO}_{2}$-equivalent $\left(\mathrm{CO}_{2}\right.$-eq) to $155.56 \mathrm{Pg} \mathrm{CO}_{2}$-eq, a decrease of $1.41 \mathrm{Pg} \mathrm{CO}_{2}$-eq. Compared with previous research results, the GHGV model proved to be an important supplementary method for estimating the potential storage of GHGs in forest ecosystems, especially in highly fragmented landscapes at a large scale. Our study indicated that the impact of forest ecosystems changes on potential GHG storage was serious during the study period. Our findings highlight that the GHGV model can be an effective and low-cost strategy to simulate the forest change and corresponding GHG storage. And considering the efficiency of the model and the historical analysis results of many periods, some of the results can also be used to inform the future afforestation programs and assess the expected GHG storage in China.
\end{abstract}

Keywords: forest; greenhouse gas; $\mathrm{CO}_{2} ; \mathrm{CH}_{4} ; \mathrm{N}_{2} \mathrm{O}$; greenhouse gas value model

\section{Introduction}

Practical strategies need to be developed to mitigate global warming, including increasing the ability of natural ecosystems to store atmospheric carbon [1,2]. Natural ecosystems regulate atmospheric $\mathrm{CO}_{2}$ concentration because they sequester and release $\mathrm{CO}_{2}$ at a far higher rate $[3,4]$. The effects of greenhouse gas (GHG) emissions in terrestrial ecosystems are the main drivers affecting GHG budgets [5,6]. 
Forest ecosystems are an important component in the climate system, and play a pivotal role in global biogeochemical cycling and climate regulation [7,8]. The carbon exchange between forests and the atmosphere is mainly through $\mathrm{CO}_{2}$, which provides a reliable way to limit GHG emissions $[9,10]$. Analysis shows that $87 \%$ of the net $\mathrm{CO}_{2}$ emissions between 1850 and 2000 were related to deforestation [11-13]. Plant biomass and soils are the potential carbon pools in forest [14,15]. Therefore, selecting effective measures to improve carbon storage in forest ecosystems has received considerable critical attention [16].

Forest soils are widely known as important terrestrial sinks for atmospheric GHGs [17]. The transformation of forest ecosystems also has an important impact on soil organic carbon storage $[5,18,19]$. However, previous research results on vegetation and soil organic carbon storage of forests have varied considerably [20]. The carbon storage of vegetation ranged from $4.38 \mathrm{Pg}$ to 8.72 Pg [21-25], while the carbon storage of soil ranged from 17.39 Pg to 23.21 Pg [22,25,26]. Quantifying the major GHGs that are stored in forest ecosystems has become a central issue when assessing forest ecosystem services.

In recent decades, researchers have become interested in estimating carbon storage through machine learning and model simulation $[27,28]$. Studies have successfully calculated the carbon storage of terrestrial ecosystems by establishing a biomass model that converts biomass into carbon storage [29]. The greenhouse gas value (GHGV) model has been used to quantify the amount of GHGs released to the atmosphere if ecosystems were completely removed [30]. This model estimates the main GHGs from different ecosystems, including methane $\left(\mathrm{CH}_{4}\right)$ and nitrous oxide $\left(\mathrm{N}_{2} \mathrm{O}\right)$ [31,32]. These studies provide new insights into spatial-temporal distribution of carbon storage in forest ecosystems through changes in GHG emissions [33]. However, most studies on GHGs are aimed at $\mathrm{CO}_{2}$. The simulation of $\mathrm{CH}_{4}$ and $\mathrm{N}_{2} \mathrm{O}$ storage in forest ecosystems at a regional scale is still relatively rare in China. Furthermore, the spatial distribution of different types of forest ecosystems may determine whether they are a carbon source or carbon sink. In summary, assessing the carbon storage in sub-type forest landscapes is indispensable for better evaluation of the ability of forests to store carbon [34].

In our study, we used the GHGV model to estimate the amount of $\mathrm{CO}_{2}, \mathrm{CH}_{4}$, and $\mathrm{N}_{2} \mathrm{O}$ stored in the forest ecosystems and compared the simulated results with localized parameters and original parameters. Furthermore, in order to verify the simulation results of our study, GHGV was converted to $\mathrm{CO}_{2}$ by molecular weight and unit to compare the potential GHGs storage with existing research results.

\section{Materials and Methods}

\subsection{Research Data}

The data with $1 \mathrm{~km}$ spatial resolution during 1990-2015 was obtained from the Resource and Environmental Science Data Center of the Chinese Academy of Sciences (http://www.resdc.cn/) [35]. On the basis of China's vegetation map, we extracted evergreen coniferous forest (ECF), deciduous broad-leaved forest (DBLF), evergreen broad-leaved forest (EBLF), mixed forest (MF), and shrubbery (Sh) by converting the land-use data into the United States Geological Survey (USGS) ecosystem types.

According to the geographical characteristics of China [36], we divided China into seven eco-geographic regions: Northeast China (NE_Ch), Inner Mongolia (IM_Ch), Northwest China (NW_Ch), Qinghai-Tibet region (QT_Ch), Central China (C_Ch), East China (E_Ch), and South China (S_Ch). These classes helped to reveal the change characteristics of forest ecosystems in different regions.

\subsection{Theory of Greenhouse Gas Value (GHGV) Model}

The GHGV model for forest ecosystems estimates the continuous exchanges of GHGs that occur among forest ecosystems and the atmosphere over centuries by completely removing the ecosystems. Other disturbances that affected the GHG exchanges between the forest ecosystems and the atmosphere also were taken into consideration. The GHGV model converted other GHGs into their $\mathrm{CO}_{2}$ equivalent to quantify the amount of GHG absorbed by forest ecosystems through radiative forcing. We set 
the simulation time $\left(t_{A}\right)$ as 100 years to indicate the biomass oxidation in forest ecosystems and the potential GHGs contribution to global warming. The GHGV model can be described as:

$$
G H G V_{t_{A}}^{\delta_{E}}=\frac{\int_{t_{A}=0}^{\delta_{A}}\left[R F_{G H G}^{\delta_{E}}\left(t_{A}\right) w\left(t_{A}\right)\right] d t_{A}}{\int_{t_{A}=0}^{\delta_{A}}\left[R F_{p C O_{2}}\left(t_{A}\right) w\left(t_{A}\right)\right] d t_{A}},
$$

where $R F_{G H G}^{\delta_{E}}\left(t_{A}\right)$ represents the enhanced radiative forcing as the GHG released after removing the specific ecosystem completely at $t_{A}$ during the $\delta_{E}$ period, and $R F_{p \mathrm{CO}_{2}}\left(t_{A}\right)$ represents the radiative forcing value led by the $\mathrm{CO}_{2}$ pulse at $t_{A}=0$.

$$
R F\left(t_{A}\right)=\sum_{x} a_{x} C_{x}^{\delta_{E}}\left(t_{A}\right),
$$

where $a_{x}$ is the radiance of each GHG $x$ (i.e., $\mathrm{CO}_{2}, \mathrm{CH}_{4}, \mathrm{~N}_{2} \mathrm{O}$ ), and $C_{x}^{\delta_{E}}$ is expressed by the following formula:

$$
C_{x}^{\delta_{E}}\left(t_{A}\right)=\int_{t_{E}=0}^{\min \left(\delta_{E}, t_{A}\right)}\left[\frac{I_{x}\left(t_{E}\right)}{A} \rho_{x}\left(t_{A}-t_{E}\right)\right] d t_{E}
$$

where $I_{x}\left(\mathrm{kmol} \times \mathrm{ha}^{-1}\right.$ year $\left.{ }^{-1}\right)$ represents the amount of GHG $x$ transported from the forest ecosystems to the atmosphere; the molar value of the atmosphere expresses as $A$; and $\rho_{x}$ represents the current GHG in the atmosphere at $t_{A}$, which uses the attenuation of one pulse of GHG $x$ to estimate.

$$
I_{x}\left(t_{E}\right)=S_{x}\left(t_{E}\right)-F_{x}\left(t_{E}\right)
$$

as the organic matter to be cleared from the land (e.g., oxidative combustion and decomposition of organic matter), we express the potential released GHG as $S_{x}$, and $F_{x}$ is the annual GHG flux of the ecosystem.

When organic matter is decomposed and burned, the released GHG can be described as:

$$
S_{x}\left(t_{E}\right)=\sum_{p}\left(O M_{p}\left\{\begin{array}{ll}
f_{p}^{c} E_{x, p}^{c} & t_{E}=0 \\
\left(1-f_{p}^{c}\right) E_{x, p}^{d} d_{p}\left(t_{E}\right) & t_{E}>0
\end{array}\right)\right.
$$

where $O M_{p}\left(\mathrm{Mg}\right.$ dry matter/ha) is the organic biomass in the ecotype $p$-zone, $f_{p}^{c}$ and $1-f_{p}^{c}$ are the proportions of the oxidative combustion and decomposition of organic matter, $E_{x, p}^{c}$ and $E_{x, p}^{d}$ ( $\mathrm{kmol} x \mathrm{Mg}^{-1}$ dry matter) represent the release ratio of the GHG $x$ produced by the oxidative combustion and decomposition for organic matter, $d_{p}\left(t_{E}\right)$ represents an exponential decay function, which indicates the annual decomposition rate of organic matter $\left(0<d_{p}\left(t_{E}\right)<1\right)$.

\subsection{Meta-Analysis of Localization Parameters}

It is crucial to select suitable parameters for the GHGV model. The GHGV model has original global parameters for various ecosystems, but these needed further verification to see whether the model original parameters were suitable for China. To ensure more accurate simulation results, we collated data that related to localized GHGV parameters for forest ecosystem types at a large-scale in China from a literature search of relevant journal articles and carried out a meta-analysis. Based on the GHGV model and the availability of data that correspond to our research, vegetation biomass density (VBD), surface biomass density (SBD), underground root biomass density (URBD), litter/leaf organic matter density (LOMD), soil organic matter density (SOMD), and $\mathrm{CO}_{2}$ flux $\left(\mathrm{CO}_{2} \mathrm{~F}\right)$ were considered.

For a broader representation of the parameters, we considered the parameters on the basis of large spatial and temporal scales, and we only took national research into consideration. We did not base our criteria on selecting long-term monitoring data. Although our simulation was over a long time (about 100 years), to ensure that the initial parameters were less sensitive to the model, we took average values if there were several referenced research results. 


\section{Results}

\subsection{Localized Model Parameters}

Previous studies provided multiple data about the model parameters and we selected the averages for the model parameters after converting units for these values. [37]. The conversion coefficients of the forest between biomass and carbon were 0.5, which referred to the values reported by Fang et al. (2007) [22]. The carbon content of litter was based on Wang et al. (1999): humus was 0.58, trunk was 55.4, branches were 46.53 , leaves were 45.84 , and roots were 53.9 [38]. The VBD calculation was based on the vegetation resources inventory while the biomass amount was estimated using a biomass-accumulation model. The SBD and URBD was calculated from the vegetation biomass and rhizome ratio labeled by Huang et al. (2006) for different ecosystem types: forest was 0.265, and shrubbery was 0.91 [39]. The LOMD and SOMD data were collected from previous studies [24]. For the $\mathrm{CO}_{2} \mathrm{~F}$, we counted the mean value of annual $\mathrm{CO}_{2} \mathrm{~F}$ over many years (2000-2014) for forest ecosystems using the Carbon Tracker data products from the National Oceanic and Atmospheric Administration Earth System Research Laboratory [40]. Based on the above analysis, the GHGV model parameters were finalized as shown in Table 1.

Table 1. The greenhouse gas value (GHGV) model's localized parameters of China's forest ecosystems.

\begin{tabular}{|c|c|c|c|c|c|c|c|}
\hline $\begin{array}{c}\text { Forest Ecosystem } \\
\text { Type }\end{array}$ & $\begin{array}{l}\text { VBD } \\
\text { (Mg/ha) }\end{array}$ & $\begin{array}{l}\text { SBD } \\
\text { (Mg/ha) }\end{array}$ & $\begin{array}{l}\text { URBD } \\
\text { (Mg/ha) }\end{array}$ & $\begin{array}{l}\text { LOMD } \\
\text { (Mg/ha) }\end{array}$ & $\begin{array}{l}\text { SOMD } \\
\text { (Mg/ha) }\end{array}$ & $\begin{array}{c}\mathrm{CO}_{2} \mathrm{~F} \\
\text { (kmol/ha·Year) }\end{array}$ & Reference \\
\hline Sh & 15.85 & 8.30 & 7.56 & 9.07 & 74.20 & 55.68 & \multirow{5}{*}[23,24,38,39]{} \\
\hline MF & 120.21 & 95.02 & 25.19 & 19.00 & 235.46 & 59.36 & \\
\hline DBLF & 128.65 & 101.70 & 26.96 & 12.72 & 194.65 & 92.29 & \\
\hline EBLF & 222.59 & 175.96 & 46.63 & 10.63 & 187.09 & 37.00 & \\
\hline ECF & 126.37 & 99.90 & 26.48 & 13.65 & 150.07 & 70.26 & \\
\hline
\end{tabular}

Note: The acronyms in Table 1 are Vegetation Biomass Density (VBD), Surface Biomass Density (SBD), Underground Root Biomass Density (URBD), Litter/Leaf Organic Matter Density (LOMD), Soil Organic Matter Density (SOMD), $\mathrm{CO}_{2}$ Flux $\left(\mathrm{CO}_{2} \mathrm{~F}\right)$; Shrubbery (Sh), Mixed forest (MF), Deciduous broad-leaved forest (DBLF), Evergreen broad-leaved forest (EBLF), Evergreen coniferous forest (ECF).

\subsection{Spatial and Temporal Changes to Forest Ecosystems from 1990 to 2015}

Figures 1 and 2 showed the spatio-temporal changes in China's forest ecosystems. Forest ecosystems were primary distributed in E_Ch, northern NE_Ch, and S_Ch, constituting approximately 74.7\% of the total forest area in China (Figures 1 and 2). The forest ecosystems area in QT_Ch and C_Ch accounted for $21.9 \%$ of China 's total forest ecosystems, while the smallest area of forest $(1.9 \%)$ was found in IM and NW_Ch.

Overall, from 1990 to 2015 , the national forest ecosystems area decreased by $15 \times 10^{5}$ ha. There was an increase in area in 1995 and there was relative stability after 2000. There were minor fluctuations during the last 25 years in each region in China, but only NE_Ch decreased by $2.5 \%$. The reduction of NE_Ch was mainly due to DBLF and MF. Of the various forest ecosystem types, MF covered the most area making up approximately $50 \%$ of the total forest, followed by Sh. Sh increased slightly (by $0.82 \%$ ) from 1990 to 2015. The DBLF, EBLF, ECF, and MF areas decreased totally. In addition, DBLF showed the greatest decrease in area $(4.46 \%)$.

\subsection{Potential Greenhouse Gas (GHG) Storage in Forest Ecosystems in China}

The total GHGs stored in China's forest ecosystems showed an overall-downward trend in our study period. The GHGV decreased by $1.41 \mathrm{Pg} \mathrm{CO}_{2}$-eq during 1990-2015. Figure 3 showed an overview of the potential storage of GHGs in each region. The region with the largest GHGV was NE_Ch, and this region also showed the largest decline of $11.99 \mathrm{Pg} \mathrm{CO}_{2}$-eq. Generally, the GHGV of regions other than NE_Ch in China remained relatively stable from 1990 to 2015. QT_Ch and S_Ch showed slight 
decreases of $0.03 \mathrm{Pg} \mathrm{CO}_{2}$-eq and $0.17 \mathrm{Pg} \mathrm{CO}_{2}$-eq, respectively. IM_Ch, NW_Ch, and E_Ch increased slightly by up to $0.1 \mathrm{Pg} \mathrm{CO}$-eq in the 25 years. For the different forest ecosystems (Figures 4 and 5), the GHGV of the DBLF, MF, and ECF decreased by $0.72 \mathrm{Pg} \mathrm{CO}_{2}$-eq (4.46\%), $0.68 \mathrm{Pg} \mathrm{CO}_{2}$-eq (no more than $1 \%$ ), and $0.12 \mathrm{Pg} \mathrm{CO}_{2}$-eq, respectively. Only Sh increased, by $0.12 \mathrm{Pg} \mathrm{CO}_{2}$-eq. The GHGs stored by DBLF and MF decreased by $0.42 \%$ and $0.33 \%$, respectively, in NE_Ch. Only EBLF and Sh increased by $4.05 \%$ and $0.38 \%$. The potential storage of GHG in forest ecosystems is critical to the GHG balance and climate regulation. The downward trend indicates that the capability of forest ecosystems to capture GHGs in China is declining.

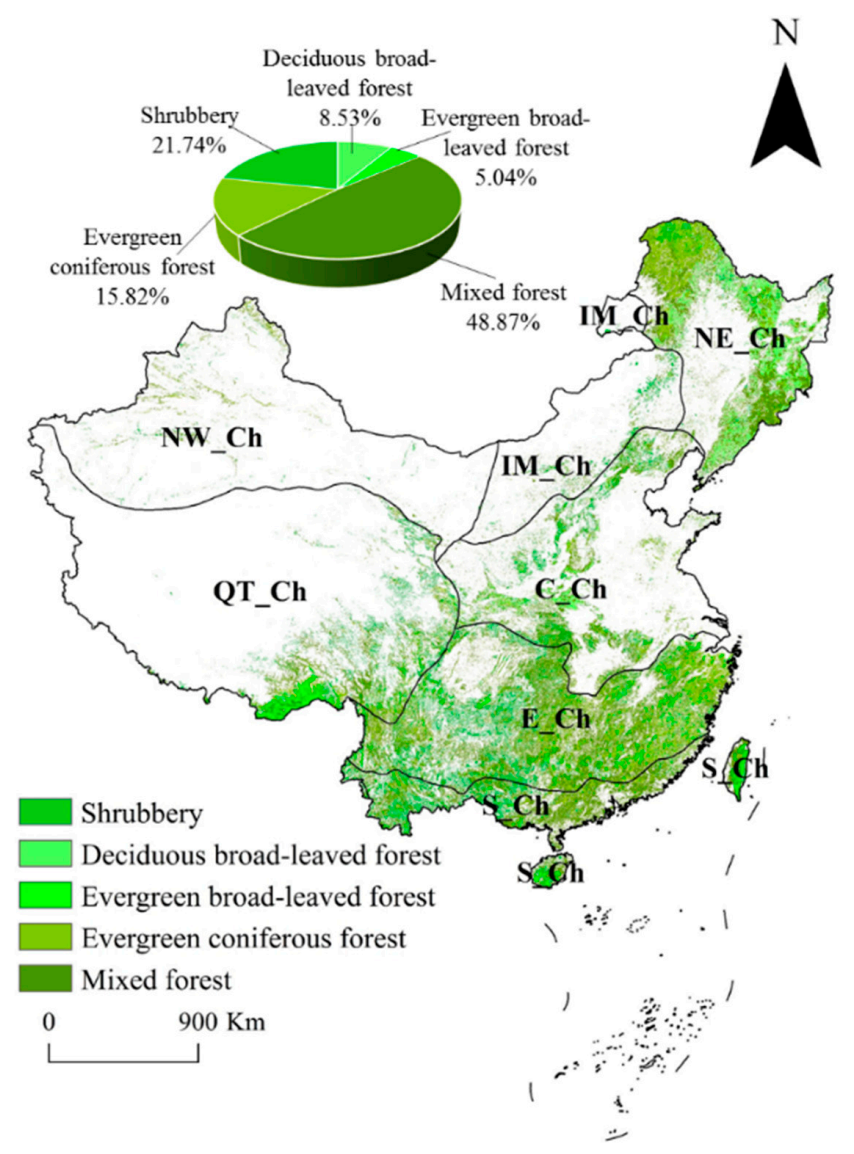

Figure 1. Spatial distribution and proportional area of forest ecosystems in China, 2015. The acronyms are Northeast China (NE_Ch), Inner Mongolia (IM_Ch), Northwest China (NW_Ch), Qinghai-Tibet (QT_Ch), Central China (C_Ch), East China (E_Ch), South China (S_Ch), and China, respectively.
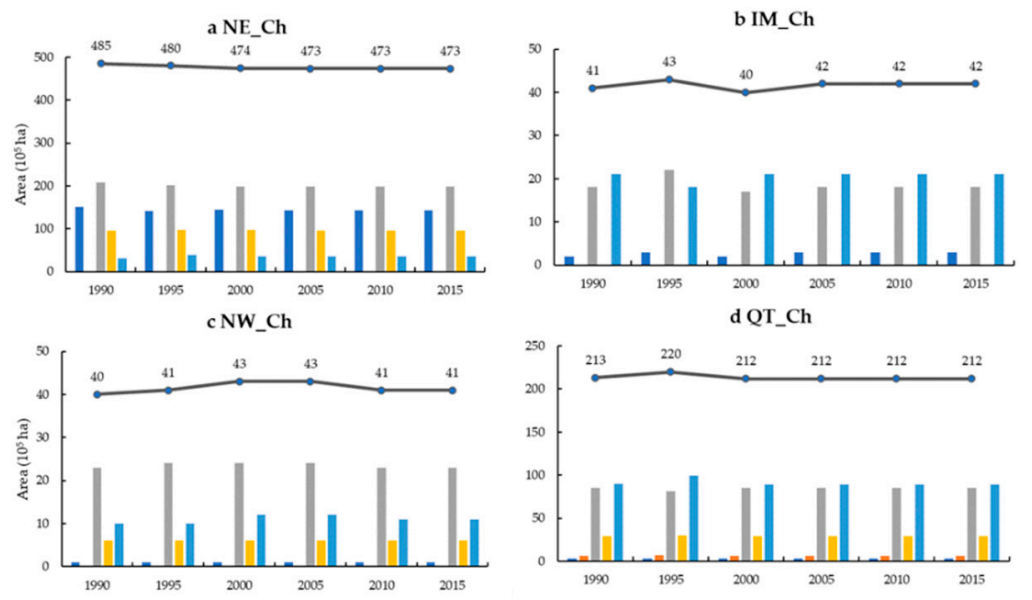

Figure 2. Cont. 

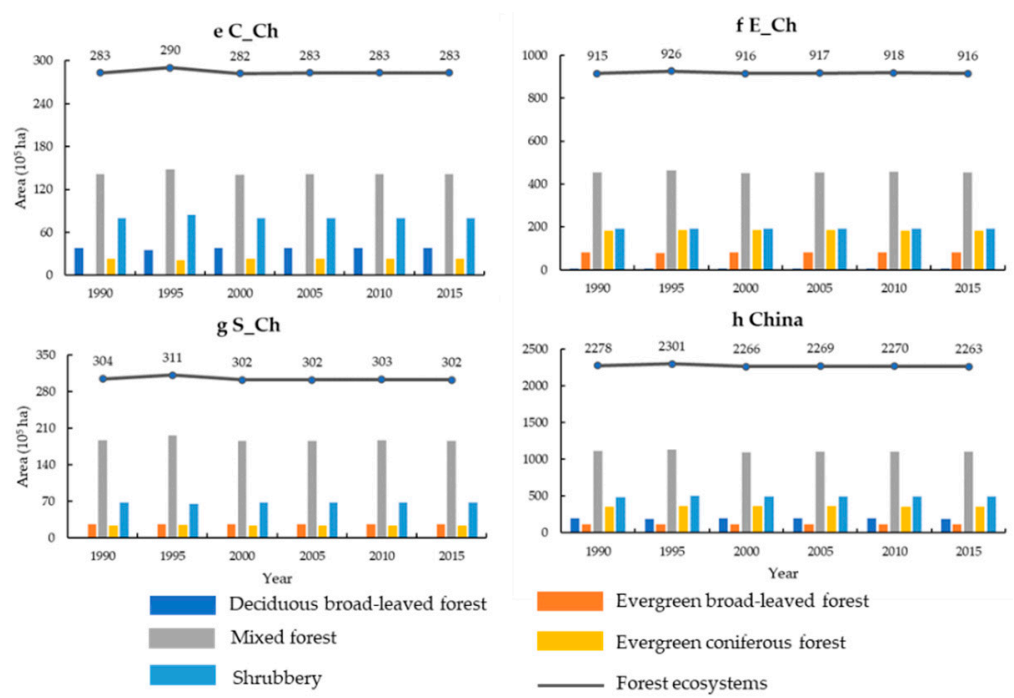

Figure 2. The area changes of China's forest ecosystems during 1990-2015. The acronyms in (a-h) are Northeast China (NE_Ch), Inner Mongolia (IM_Ch), Northwest China (NW_Ch), Qinghai-Tibet (QT_Ch), Central China (C_Ch), East China (E_Ch), South China (S_Ch), and China, respectively.
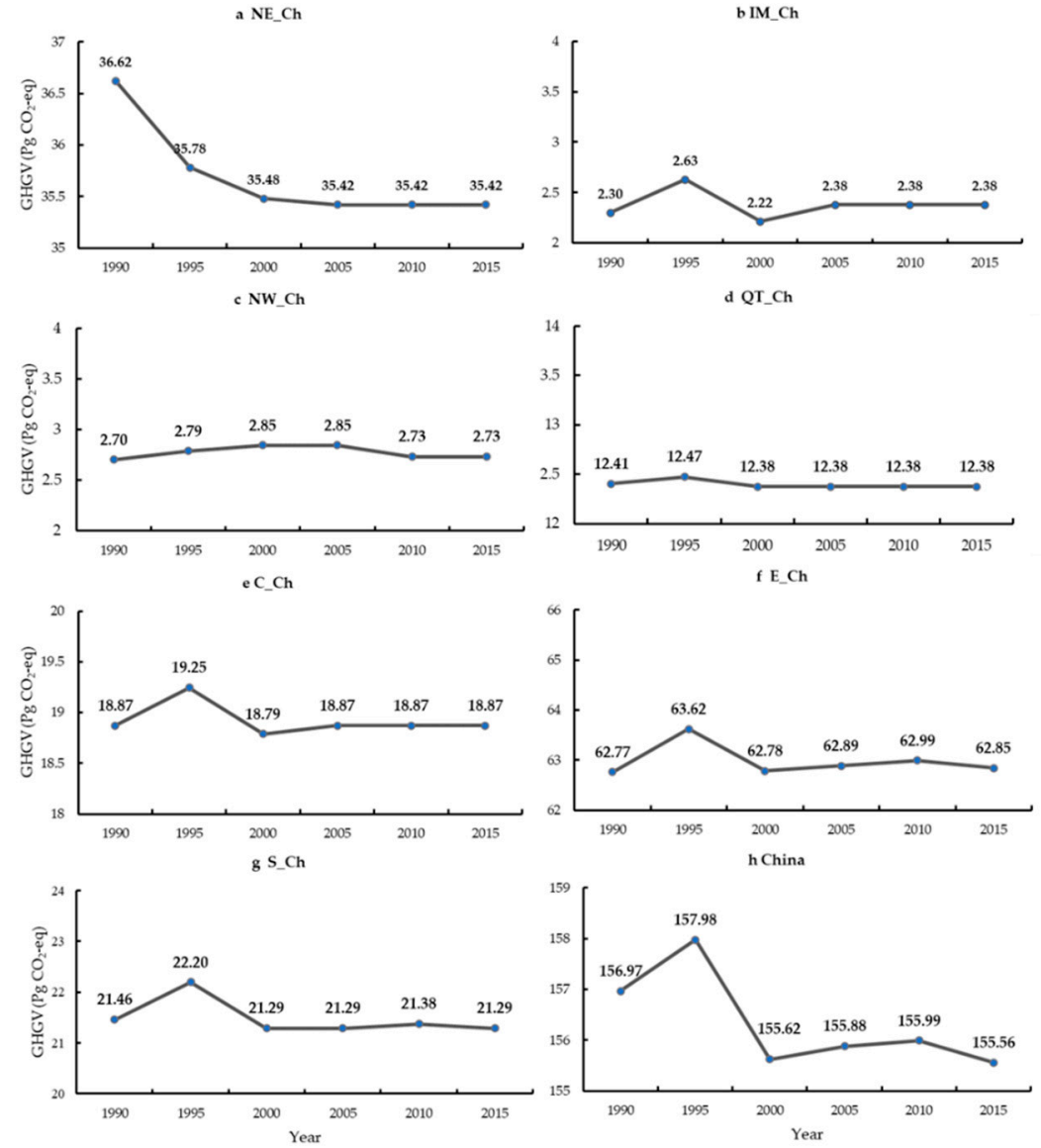

Figure 3. Changes of greenhouse gas value (GHGV) for forest ecosystems among various eco-geographical regions in China during 1990-2015. The acronyms in (a-h) are Northeast China (NE_Ch), Inner Mongolia (IM_Ch), Northwest China (NW_Ch), Qinghai-Tibet (QT_Ch), Central China (C_Ch), East China (E_Ch), South China (S_Ch), and China, respectively. 

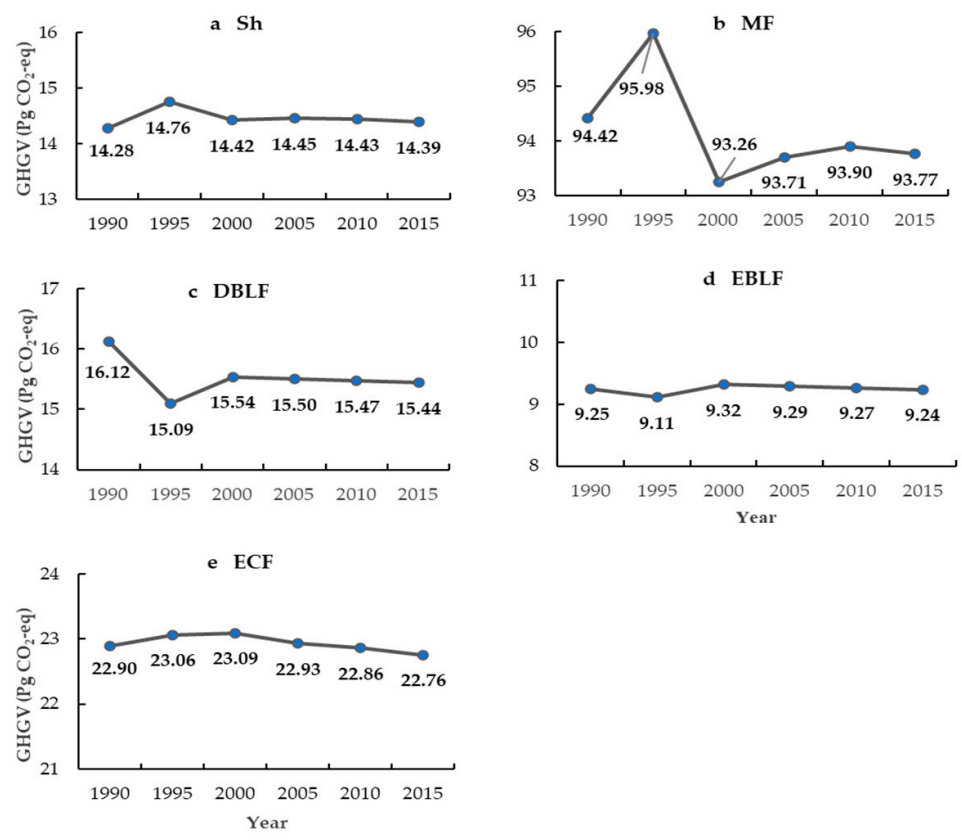

Figure 4. Changes of greenhouse gas value (GHGV) in China's various forest ecosystems during1990-2015. The acronyms in (a-e) are Shrubbery (Sh), Evergreen coniferous forest (ECF), Mixed forest (MF), Evergreen broad-leaved forest (EBLF), and Deciduous broad-leaved forest (DBLF).

a

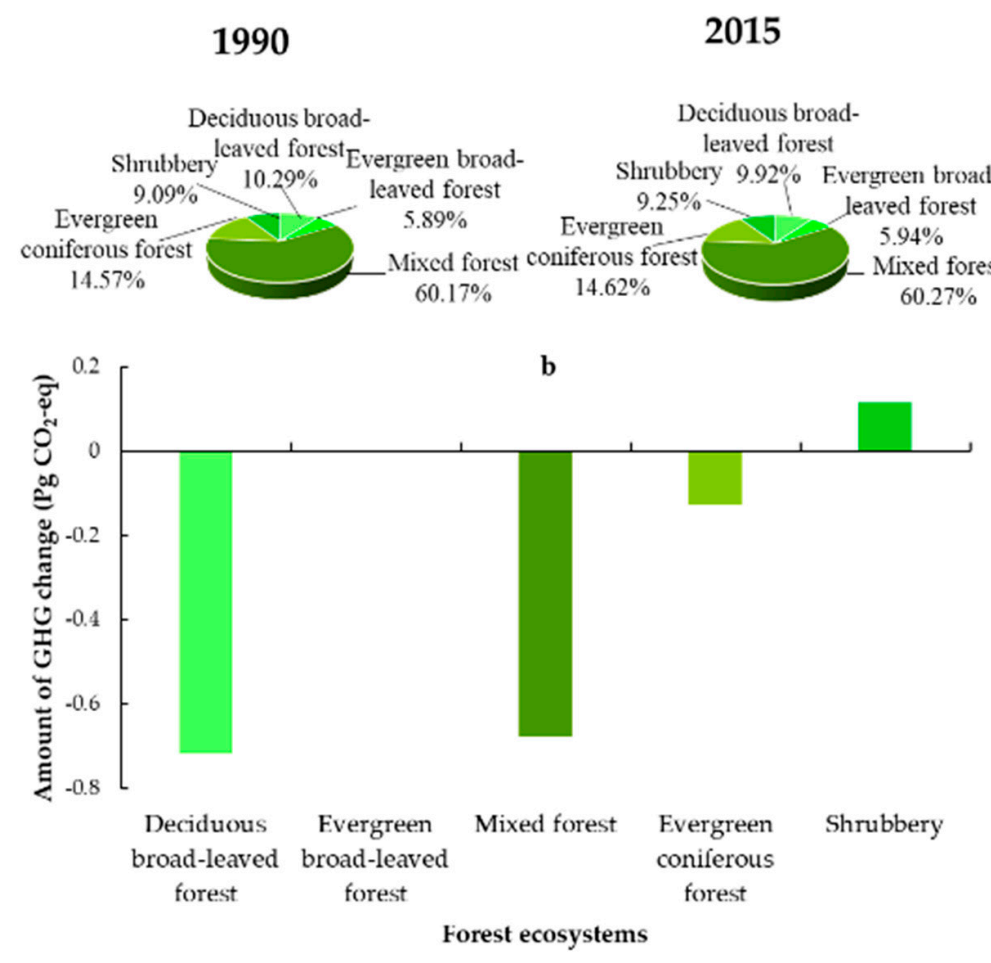

Figure 5. Greenhouse gas (GHG) change in different forest ecosystems: (a) Proportion of GHG in various forest ecosystems in 1990 and 2015; (b) Amount of GHG change in various forest ecosystems in China during 1990-2015.

\subsection{Comparison of Results with Localized Parameters and Model Original Parameters}

We also compared the GHGV using the original parameters (_Op) with that of the localized parameters (_Lp) for forest ecosystems in China. The comparison of the total GHGV for forest ecosystems with the two sets of parameters from 1990 to 2015 indicated that the model original parameters did not 
perform well in China's forest ecosystems, with values far beyond those using localized parameters. The multi-year average GHGV of the model original parameters was higher than that of localized parameters; the difference between them was $120.3 \mathrm{Pg} \mathrm{CO}_{2}$-eq. There were few inter-annual fluctuations in GHGV for localized parameters and model original parameters.

Figure 6 compares the results of localized parameters and those of model original parameters during 100 years. The GHGV in China's forest ecosystems increased fast in the first 10 years. The GHGV inter-year variations between BLF and MF in China were similar. The original global temperate forest remained far above that of other ecosystems during the simulation period. The GHGV differences between global coniferous forest and global Sh gradually reduced over 100 years. However, the GHGV annual change of DBLF, EBLF, and MF in the last 50 years increased by less than $1.5 \mathrm{Mg} \mathrm{CO}$-eq/ha. The ECF GHGV in China was parallel with that of global coniferous forest. The GHGV of China's Sh was lower than that of global Sh during the simulation periods. However, although the amounts tended to vary, the GHGV trends in China's forest ecosystems were consistent with those of global forest ecosystems during the study periods.

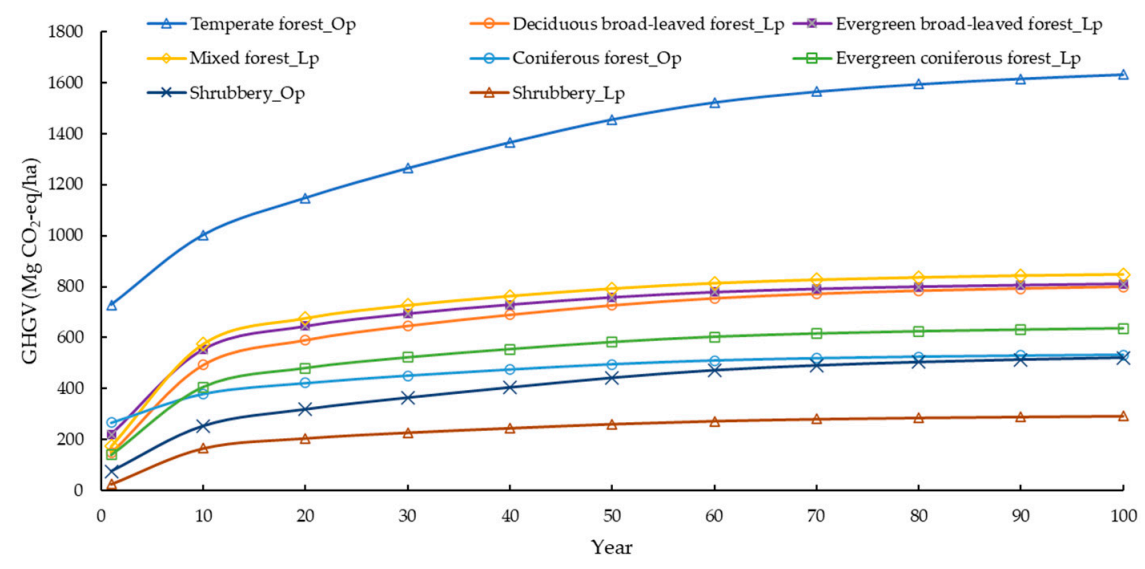

Figure 6. Temporal changes of greenhouse gas value (GHGV) in China's forest ecosystems (GHGV with localized parameters,_Lp) and global forest ecosystems (GHGV with model original parameters,_Op).

\section{Discussion}

Our comparison of the GHGV simulation results found large differences using the localized parameters and the model original parameters. We deliberated certain reasons for this. Our research developed the three forest ecosystem types of the original model into five forest ecosystem types. Although there were several studies on forest ecosystem types with detailed classifications that influenced the GHGV [41,42], the difference in forest ecosystem classification may have created heterogeneous uncertainty in the same forest ecosystem type.

Firstly, in our study, the main reduction in forest area was in NE_Ch. Secondly, the localized parameters and the original parameters of our research had some quite different values (Figure 7). Comparing the parameters between various forest ecosystems in China and globally, we found that the URBD of various forest ecosystems was similar to the SBD. The global temperate forest SBD was larger than that of BLF and MF in China. There were many secondary forests and young forests in China, which may cause the SBD values of the global coniferous forest and global Sh to be larger than corresponding forest types in China. Almost all the parameters varied from the original model parameters to a greater or lesser extent.

It can be hard to compare the potential GHGs storage with existing research results. In this study, the GHGV was converted to $\mathrm{CO}_{2}$ by molecular weight and unit. Although there were many studies about carbon cycles in China's forest ecosystems, the useable research for our study were limited by sample data and analysis methods [23,43,44]. Table 2 provides the summary statistics for carbon storage and forest area from other studies and this study. The most obvious finding to emerge from the table was that the forest ecosystems area data we used was larger than others. The forest 
ecosystems area $\left(227 \times 10^{6}\right.$ ha) used in our study, were close to the eighth China forest resources inventory $\left(208 \times 10^{6} \mathrm{ha}\right)$ and the interpreted area $\left(202 \times 10^{6} \mathrm{ha}\right)$ based on multiple satellite data $[25,45]$. Although China's forest ecosystems can act as a carbon sink [46-48], we found that the carbon storage of forest ecosystems in China decreased by $0.152 \mathrm{Pg} \mathrm{C} / 10$ years, simulated by localized parameters. Deforestation and cultivated land reclamation may bring about a decrease in GHGs sequestered by forest ecosystems in most regions of China [49,50].
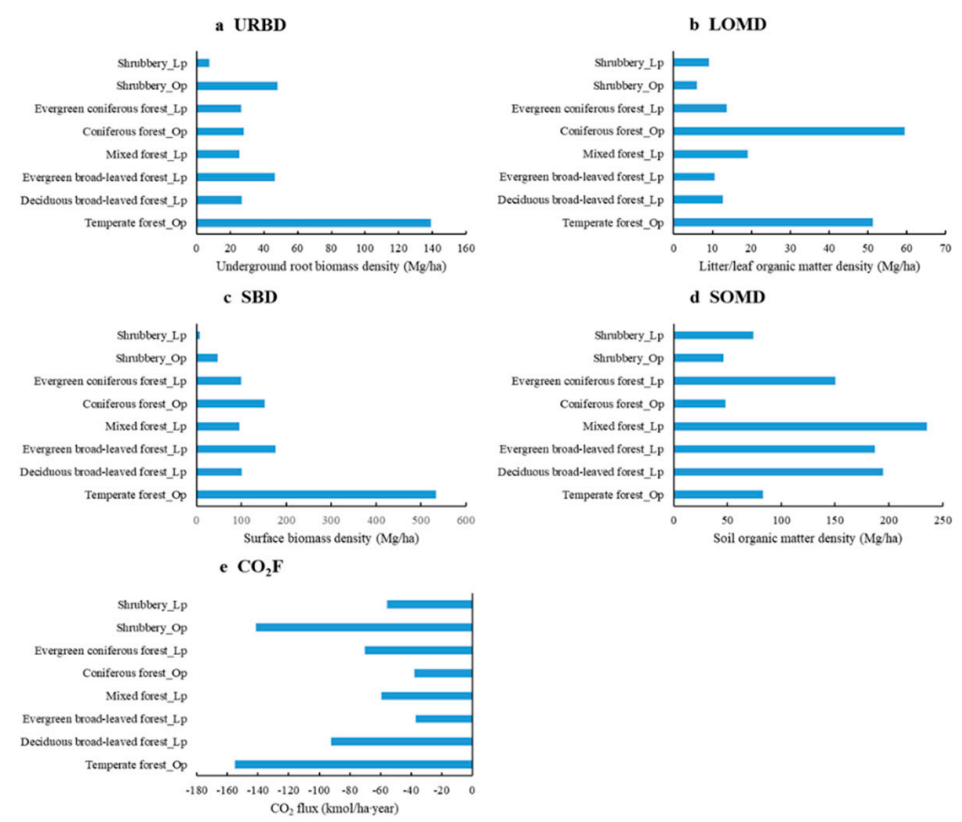

Figure 7. Comparison of model parameters for forest ecosystem types based on the localized parameters (their suffix is_Lp) and three similar ecosystem types with original global model parameters (their suffix is_Op) in China. The acronyms in (a-e) are Underground root biomass density (URBD), Litter/leaf organic matter density (LOMD), Surface biomass density (SBD), Soil organic matter density (SOMD), and $\mathrm{CO}_{2}$ Flux $\left(\mathrm{CO}_{2} \mathrm{~F}\right)$.

Table 2. Results of carbon storage and forest area in previous researches and this study.

\begin{tabular}{cccc}
\hline Reference & Area $\left(\mathbf{1 0}^{\mathbf{6}} \mathbf{h a )}\right.$ & Carbon Storage (Pg C) & $\begin{array}{c}\text { Carbon Density } \\
\text { (Pg C/106 } \mathbf{~ h a ) ~}\end{array}$ \\
\hline Fang et al. (1981) [21] & 116.5 & 16.38 & 0.14 \\
\hline Zhou et al. (1989/1993) [24] & 108.62 & 28.11 & 0.26 \\
\hline Li et al. (1981/1998) [23] & 121.63 & 31.93 & 0.26 \\
\hline Zhao (1996/1999) [51] & 129.12 & 19.91 & 0.15 \\
\hline Fang et al. (2000) [22] & 142.8 & 22.48 & 0.16 \\
\hline $\begin{array}{c}\text { The eighth forest inventory } \\
\text { (2009/2013) [25] }\end{array}$ & 208 & 32.11 & 0.15 \\
\hline Xie et al. (2004) [26] & 150 & 23.58 & 0.16 \\
\hline This study (1990) & 227.8 & 42.81 & 0.19 \\
\hline This study (2015) & 226.3 & 42.43 & 0.19 \\
\hline
\end{tabular}

Our study also revealed that the GHGV model can support measured or inventory data. Although the analysis of actual observations is irreplaceable, it is undeniable that models are well suited to large scale simulations. Furthermore, the simulation results for different regions can be analyzed in a unified framework around the world. In terms of GHG density, our study was within the range of other studies. However, it is not useful to simply compare the GHG values, and more analysis should be conducted in combination with the area of the forest (Table 2). Another reason for the differences 
among studies related to the centennial-scale simulation results are that they are not sensitive to variations over short time frames. Therefore, the limitations of the GHGV model itself still need to be considered in specific research.

\section{Conclusions}

This study analyzed the spatiotemporal changes in forest ecosystems in China from 1990 to 2015 and simulated the potential storage of GHGs in China's forest ecosystems using the GHGV model. We compared the model's original parameters and localized parameters. The area of China's forest ecosystems decreased by $15 \times 10^{5}$ ha between 1990 and 2015. Correspondingly, the simulation results indicated that the GHGs stored by China's forest ecosystems dropped from $156.97 \mathrm{Pg} \mathrm{CO}_{2}$-eq to $155.56 \mathrm{Pg} \mathrm{CO}_{2}$-eq.

Our study found that existing research results were a useful supplement to sampling observations. There were many significant advantages in model simulation on a large scale. The uncertainty in model factors driven by greater human disturbances and the differences among specific forest ecosystems at various stages of growth should be taken into consideration when using the GHGV model.

Author Contributions: Conceptualization, M.L. and Y.C.; methodology, M.L., Y.C., and Y.Q.; software, M.L., X.L., and Y.R.; formal analysis, Y.C., M.L., Y.F., N.L., and O.G.C.; writing-original draft preparation, Y.C. and M.L.; writing-review and editing, Y.C.; supervision, Y.C.; funding acquisition, Y.C. All authors have read and agreed to the published version of the manuscript.

Funding: This research was funded by Natural Science Foundation of China (42071415 and 41671425) and Outstanding Youth Foundation of Henan Natural Science Foundation (Y.C.).

Acknowledgments: The authors acknowledge the Resource and Environmental Science Data Center of the Chinese Academy of Sciences (http://www.resdc.cn/) for providing land use data.

Conflicts of Interest: The authors declare no conflict of interest.

\section{References}

1. Griscom, B.W.; Adams, J.; Ellis, P.W.; Houghton, R.A.; Lomax, G.; Miteva, D.A.; Schlesinger, W.H.; Shoch, D.; Siikamaki, J.V.; Smith, P.; et al. Natural climate solutions. Proc. Natl. Acad. Sci. USA 2017, 114, 11645-11650. [CrossRef] [PubMed]

2. O'Connor, J.J.; Fest, B.J.; Sievers, M.; Swearer, S.E. Impacts of land management practices on blue carbon stocks and greenhouse gas fluxes in coastal ecosystems-a meta-analysis. Glob. Chang. Biol. 2020, 26, 1354-1366. [CrossRef] [PubMed]

3. Lu, F.; Hu, H.; Sun, W.; Zhu, J.; Liu, G.; Zhou, W.; Zhang, Q.; Shi, P.; Liu, X.; Wu, X.; et al. Effects of national ecological restoration projects on carbon sequestration in China from 2001 to 2010. Proc. Natl. Acad. Sci. USA 2018, 115, 4039-4044. [CrossRef]

4. Murdiyarso, D.; Purbopuspito, J.; Kauffman, J.B.; Warren, M.W.; Sasmito, S.D.; Donato, D.C.; Manuri, S.; Krisnawati, H.; Taberima, S.; Kurnianto, S. The potential of Indonesian mangrove forests for global climate change mitigation. Nat. Clim. Chang. 2015, 5, 1089-1092. [CrossRef]

5. Deng, L.; Huang, C.; Kim, D.G.; Shangguan, Z.; Wang, K.; Song, X.; Peng, C. Soil GHG fluxes are altered by N deposition: New data indicate lower $\mathrm{N}$ stimulation of the $\mathrm{N}_{2} \mathrm{O}$ flux and greater stimulation of the calculated C pools. Glob. Chang. Biol. 2020, 26, 2613-2629. [CrossRef]

6. Li, M.; Cui, Y.; Fu, Y.; Li, N.; Tang, X.; Liu, X.; Run, Y. Simulating the potential sequestration of three major greenhouse gases in China's natural ecosystems. Forests 2020, 11, 128. [CrossRef]

7. Allen, C.D.; Macalady, A.K.; Chenchouni, H.; Bachelet, D.; McDowell, N.; Vennetier, M.; Kitzberger, T.; Rigling, A.; Breshears, D.D.; Hogg, E.H.; et al. A global overview of drought and heat-induced tree mortality reveals emerging climate change risks for forests. For. Ecol. Manag. 2010, 259, 660-684. [CrossRef]

8. Li, J.; Delgado-Baquerizo, M.; Wang, J.; Hu, H.; Cai, Z.; Zhu, Y.; Singh, B.K. Fungal richness contributes to multifunctionality in boreal forest soil. Soil Biol. Biochem. 2019, 136. [CrossRef]

9. Cui, Y.; Meadows, M.E.; Li, N.; Fu, Y.; Zhao, G.; Dong, J. Land cover change intensifies actual and potential radiative forcing through $\mathrm{CO}_{2}$ in South and Southeast Asia from 1992 to 2015. Int. J. Environ. Res. Public Health 2019, 16, 2460. [CrossRef] 
10. Schimel, D.; Stephens, B.B.; Fisher, J.B. Effect of increasing $\mathrm{CO}_{2}$ on the terrestrial carbon cycle. Proc. Natl. Acad. Sci. USA 2015, 112, 436-441. [CrossRef]

11. Houghton, R.A. Revised estimates of the annual net flux of carbon to the atmosphere from changes in land use and land management 1850-2000. Tellus Ser. B Chem. Phys. Meteorol. 2003, 55, 378-390.

12. Houghton, R.A.; Hackler, J.L.; Lawrence, K.T. The US carbon budget: Contributions from land-use change. Science 1999, 285, 574-578. [CrossRef]

13. Le Quere, C.; Andrew, R.M.; Friedlingstein, P.; Sitch, S.; Hauck, J.; Pongratz, J.; Pickers, P.A.; Korsbakken, J.I.; Peters, G.P.; Canadell, J.G.; et al. Global carbon budget 2018. Earth Syst. Sci. Data 2018, 10, 2141-2194. [CrossRef]

14. Meena, A.; Bidalia, A.; Hanief, M.; Dinakaran, J.; Rao, K.S. Assessment of above and belowground carbon pools in a semi-arid forest ecosystem of Delhi, India. Ecol. Process. 2019, 8, 8. [CrossRef]

15. Zhang, C.; Li, X.; Chen, Y.; Zhao, J.; Wan, S.; Lin, Y.; Fu, S. Effects of eucalyptus litter and roots on the establishment of native tree species in eucalyptus plantations in South China. For. Ecol. Manag. 2016, 375, 76-83. [CrossRef]

16. Chen, L.; Guan, X.; Li, H.; Wang, Q.; Zhang, W.; Yang, Q.; Wang, S. Spatiotemporal patterns of carbon storage in forest ecosystems in Hunan Province, China. For. Ecol. Manag. 2019, 432, 656-666. [CrossRef]

17. Feng, H.; Guo, J.; Han, M.; Wang, W.; Peng, C.; Jin, J.; Song, X.; Yu, S. A review of the mechanisms and controlling factors of methane dynamics in forest ecosystems. For. Ecol. Manag. 2020, 455, 117702. [CrossRef]

18. Falkowski, P.; Scholes, R.J.; Boyle, E.; Canadell, J.; Canfield, D.; Elser, J.; Gruber, N.; Hibbard, K.; Hogberg, P.; Linder, S.; et al. The global carbon cycle: A test of our knowledge of earth as a system. Science 2000, 290, 291-296. [CrossRef]

19. Chen, Y.; Cao, J.; Zhou, L.; Li, F.; Fu, S. Effects of prescribed burning on carbon accumulation in two paired vegetation sites in subtropical China. For. Ecosyst. 2019, 6, 26. [CrossRef]

20. Chen, Y.; Yu, S.; Liu, S.; Wang, X.; Zhang, Y.; Liu, T.; Zhou, L.; Zhang, W.; Fu, S. Reforestation makes a minor contribution to soil carbon accumulation in the short term: Evidence from four subtropical plantations. For. Ecol. Manag. 2017, 384, 400-405. [CrossRef]

21. Fang, J.; Chen, A.; Peng, C.; Zhao, S.; Ci, L. Changes in forest biomass carbon storage in China between 1949 and 1998. Science 2001, 292, 2320-2322. [CrossRef] [PubMed]

22. Fang, J.; Guo, Z.; Piao, S.; Chen, A. Terrestrial vegetation carbon sinks in China, 1981-2000. Sci. China Ser. D Earth Sci. 2007, 50, 1341-1350. [CrossRef]

23. Li, K.; Wang, S.; Cao, M. Vegetation and soil carbon storage in China. Sci. China Ser. D Earth Sci. 2004, 47, 49-57. [CrossRef]

24. Zhou, Y.; Yu, Z.; Zhao, S. Carbon storage and budget of major Chinese forest types. Acta Phytoecol. Sin. 2000, 24, 518-522.

25. The State Forestry Administration of the People's Republic of China. Results of the eighth national forest resources inventory. Resour. Manag. 2014,1-2. [CrossRef]

26. Xie, X.; Sun, B.; Zhou, H.; Li, Z. Soil carbon stocks and their influencing factors under native vegetation's in China. Acta Pedol. 2004, 687-699.

27. Were, K.; Bui, D.T.; Dick, O.B.; Singh, B.R. A comparative assessment of support vector regression, artificial neural networks, and random forests for predicting and mapping soil organic carbon stocks across an afromontane landscape. Ecol. Indic. 2015, 52, 394-403. [CrossRef]

28. Zhao, M.; Yue, T.; Zhao, N.; Sun, X.; Zhang, X. Combining LPJ-GUESS and HASM to simulate the spatial distribution of forest vegetation carbon stock in China. J. Geogr. Sci. 2014, 24, 249-268. [CrossRef]

29. Sullivan, M.J.P.; Talbot, J.; Lewis, S.L.; Phillips, O.L.; Qie, L.; Begne, S.K.; Chave, J.; Cuni-Sanchez, A.; Hubau, W.; Lopez-Gonzalez, G.; et al. Diversity and carbon storage across the tropical forest biome. Sci Rep. 2017, 7, 39102. [CrossRef]

30. Anderson-Teixeira, K.J.; DeLucia, E. The greenhouse gas value of ecosystems. Glob. Chang. Biol. 2011, 17, 425-438. [CrossRef]

31. Anderson-Teixeira, K.J.; Snyder, P.K.; Twine, T.E.; Cuadra, S.V.; Costa, M.H.; DeLucia, E.H. Climate regulation services of natural and agricultural ecoregions of the Americas. Nat. Clim. Chang. 2012, 2, 177. [CrossRef]

32. Bayer, A.D.; Pugh, T.A.; Krause, A.; Arneth, A. Historical and future quantification of terrestrial carbon sequestration from a greenhouse-gas-value perspective. Glob. Environ. Chang. 2015, 32, 153-164. [CrossRef] 
33. Chazdon, R.L.; Broadbent, E.N.; Rozendaal, D.M.A.; Bongers, F.; Almeyda Zambrano, A.M.; Aide, T.M.; Balvanera, P.; Becknell, J.M.; Boukili, V.; Brancalion, P.H.S.; et al. Carbon sequestration potential of second-growth forest regeneration in the Latin American tropics. Sci. Adv. 2016, 2, e1501639. [CrossRef]

34. Chu, X.; Zhan, J.; Li, Z.; Zhang, F.; Qi, W. Assessment on forest carbon sequestration in the three-north shelterbelt program region, China. J. Clean. Prod. 2019, 215, 382-389. [CrossRef]

35. Liu, J.; Kuang, W.; Zhang, Z.; Xu, X.; Qin, Y.; Ning, J.; Zhou, W.; Zhang, S.; Li, R.; Yan, C.; et al. Spatiotemporal characteristics, patterns, and causes of land-use changes in China since the late 1980s. J. Geogr. Sci. 2014, 24, 195-210. [CrossRef]

36. Zheng, D.; Li, B. Chinese Eco-Geographic Map; Beijing Commercial Press: Beijing, China, 2005.

37. Lin, D.; Xia, J.; Wan, S. Climate warming and biomass accumulation of terrestrial plants: A meta-analysis. New Phytol. 2010, 188, 187-198. [CrossRef]

38. Wang, S.; Zhou, C. Estimating soil carbon reservoir of terrestrial ecosystem in China. Geogr. Res. 1999, 18, 349-356.

39. Huang, M.; Ji, J.; Cao, M.; Li, K. Modeling study of vegetation shoots and root biomass in China. Acta Ecol. Sin. 2006, 26, 4156-4163.

40. Van Der Laan-Luijkx, I.T.; Van Der Velde, I.R.; Van Der Veen, E.; Tsuruta, A.; Stanislawska, K.; Babenhauserheide, A.; Zhang, H.; Liu, Y.; He, W.; Chen, H.; et al. The CarbonTracker data assimilation shell (CTDAS) v1.0: Implementation and global carbon balance 2001-2015. Geosci. Model. Dev. 2017, 10, 2785-2800. [CrossRef]

41. Tang, X.; Zhao, X.; Bai, Y.; Tang, Z.; Wang, W.; Zhao, Y.; Wan, H.; Xie, Z.; Shi, X.; Wu, B. Carbon pools in China's terrestrial ecosystems: New estimates based on an intensive field survey. Proc. Natl. Acad. Sci. USA 2018, 115, 4021-4026. [CrossRef]

42. Tang, Z.; Xu, W.; Zhou, G.; Bai, Y.; Li, J.; Tang, X.; Chen, D.; Liu, Q.; Ma, W.; Xiong, G.; et al. Patterns of plant carbon, nitrogen, and phosphorus concentration in relation to productivity in China's terrestrial ecosystems. Proc. Natl. Acad. Sci. USA 2018, 115, 4033-4038. [CrossRef] [PubMed]

43. Lai, L.; Huang, X.; Yang, H.; Chuai, X.; Zhang, M.; Zhong, T.; Chen, Z.; Chen, Y.; Wang, X.; Thompson, J.R. Carbon emissions from land-use change and management in China between 1990 and 2010. Sci. Adv. 2016, 2, e1601063. [CrossRef] [PubMed]

44. Ni, J. Carbon storage in Chinese terrestrial ecosystems: Approaching a more accurate estimate. Clim. Chang. 2013, 119, 905-917. [CrossRef]

45. Qin, Y.; Xiao, X.; Dong, J.; Zhang, G.; Shimada, M.; Liu, J.; Li, C.; Kou, W.; Moore, B. Forest cover maps of China in 2010 from multiple approaches and data sources: PALSAR, Landsat, MODIS, FRA, and NFI. ISPRS J. Photogramm. Remote Sens. 2015, 109, 1-16. [CrossRef]

46. Fang, J.; Huang, Y.; Zhu, J.; Sun, W.; Hu, H. Carbon budget of forest ecosystems and its driving forces. China Basic Sci. 2015, 17, 20-25.

47. Liu, G.; Fu, B.; Fang, J. Carbon dynamics of Chinese forests and its contribution to global carbon balance. Acta Ecol. Sin. 2000, 20, 733-740.

48. Zhang, X.; Xu, D. Potential carbon sequestration in China's forests. Environ. Sci. Policy 2003, 6, 421-432. [CrossRef]

49. Miles, L.; Kapos, V. Reducing greenhouse gas emissions from deforestation and forest degradation: Global land-use implications. Science 2008, 320, 1454-1455. [CrossRef]

50. Miao, R.; Qiu, X.; Guo, M.; Ala, M.; Jiang, D. Accuracy of space-for-time substitution for vegetation state prediction following shrub restoration. J. Plant Ecol. 2016, 11, 208-217. [CrossRef]

51. Zhao, S. China ecosystem research network (CERN)-Introduction and progress. AMBIO-J. Hum. Environ. 1999, 28, 636-638.

Publisher's Note: MDPI stays neutral with regard to jurisdictional claims in published maps and institutional affiliations.

(C) 2020 by the authors. Licensee MDPI, Basel, Switzerland. This article is an open access article distributed under the terms and conditions of the Creative Commons Attribution (CC BY) license (http://creativecommons.org/licenses/by/4.0/). 